\title{
Prevalence of bacterial vaginosis in Portuguese pregnant women and vaginal colonization by Gardnerella vaginalis
}

\author{
Daniela Machado $^{1}$, Joana Castro ${ }^{1,2}$, José Martinez-de-Oliveira ${ }^{3,4}$, Cristina Nogueira-Silva ${ }^{5,6,7}$, Nuno Cerca \\ Corresp. 1 \\ ${ }^{1}$ Centre of Biological Engineering (CEB), Laboratory of Research in Biofilms Rosário Oliveira (LIBRO), University of Minho, Braga, Portugal \\ 2 Instituto de Ciências Biomédicas Abel Salazar, University of Porto, Porto, Portugal \\ 3 Women \& Child Health Department, Centro Hospitalar Cova da Beira EPE, Covilhã, Portugal \\ 4 CICS-UBI, Health Sciences Research Center, Faculty of Health Sciences, University of Beira Interior, Covilhã, Portugal \\ 5 Department of Obstetrics and Gynecology, Hospital de Braga, Braga, Portugal \\ 6 Life and Health Sciences Research Institute, School of Medicine, University of Minho, Braga, Portugal \\ 7 ICVS/3B's, Braga/Guimarães, Portugal \\ Corresponding Author: Nuno Cerca \\ Email address: nunocerca@ceb.uminho.pt
}

Background. We aimed to determine the prevalence of vaginal colonization by Gardnerella vaginalis and of bacterial vaginosis (BV) in Portuguese pregnant women, and to identify risk factors for BV and G. vaginalis colonization in pregnancy. Methods. A cross-sectional study was conducted among pregnant women aged $\geq 18$ years who were attending in two public hospitals of the Northwest region of Portugal. Epidemiological data was collected by anonymous questionnaire. BV was diagnosed by Nugent criteria and G. vaginalis presence was identified by polymerase chain reaction. Crude associations between the study variables and BV or G. vaginalis colonization were quantified by odds ratios (ORs) and their $95 \%$ confidence intervals (Cls). Results. The prevalences of BV and of $G$. vaginalis colonization among Portuguese pregnant women were $3.88 \%$ and $67.48 \%$, respectively. Previous preterm delivery and colonization by $G$. vaginalis were factors with very high OR, but only statistically significant for a $90 \% \mathrm{Cl}$. Conversely, higher rates of $\mathrm{G}$. vaginalis colonization were found in women with basic educational level (OR $=2.77,95 \%$ $\mathrm{Cl}$ [1.33-5.78]), during the second trimester of pregnancy $(\mathrm{OR}=6.12,95 \% \mathrm{Cl}[1.80-20.85])$ and with $\mathrm{BV}$ flora $(\mathrm{OR}=8.73,95 \% \mathrm{Cl}[0.50-153.60])$. Discussion. Despite the lower number of women with BV, prevalence ratios and association with risk factors were similar to recent European studies. However, the percentage of healthy women colonized by $G$. vaginalis was significantly higher than many previous studies, confirming that $G$. vaginalis colonization does not always lead to BV development. 
1 Prevalence of bacterial vaginosis in Portuguese pregnant women and vaginal colonization

2 by Gardnerella vaginalis

3

4 Daniela Machado ${ }^{1}$, Joana Castro ${ }^{1,2}$, José Martinez-de-Oliveira ${ }^{3,4}$ Cristina Nogueira-Silva $^{5,6,7}$ and

5 Nuno Cerca ${ }^{1}$

6

$7 \quad{ }^{1}$ Centre of Biological Engineering (CEB), Laboratory of Research in Biofilms Rosário Oliveira

8 (LIBRO), University of Minho, Braga, Portugal

9 2Instituto de Ciências Biomédicas Abel Salazar (ICBAS), University of Porto, Porto, Portugal

$10{ }^{3}$ CICS-UBI, Health Sciences Research Center, Faculty of Health Sciences, University of Beira

11 Interior, Covilhã, Portugal

$12{ }^{4}$ Women \& Child Health Department, Centro Hospitalar Cova da Beira EPE, Covilhã, Portugal

13 5epartment of Obstetrics and Gynecology, Hospital de Braga, Braga, Portugal

$14{ }^{6}$ Life and Health Sciences Research Institute, School of Medicine, University of Minho, Braga,

15 Portugal

16 'ICVS/3B's, Braga / Guimarães, Portugal

17

18 Corresponding author:

19 Nuno Cerca ${ }^{1}$

20 E-mail address: nunocerca@ceb.uminho.pt 


\section{ABSTRACT}

22 Background. We aimed to determine the prevalence of vaginal colonization by Gardnerella 23 vaginalis and of bacterial vaginosis $(\mathrm{BV})$ in Portuguese pregnant women, and to identify risk 24 factors for BV and G. vaginalis colonization in pregnancy.

25 Methods. A cross-sectional study was conducted among pregnant women aged $\geq 18$ years who 26 were attending in two public hospitals of the Northwest region of Portugal. Epidemiological data was collected by anonymous questionnaire. BV was diagnosed by Nugent criteria and $G$. vaginalis presence was identified by polymerase chain reaction. Crude associations between the study variables and BV or G. vaginalis colonization were quantified by odds ratios (ORs) and their 95\% confidence intervals (CIs).

31 Results. The prevalences of BV and of G. vaginalis colonization among Portuguese pregnant women were $3.88 \%$ and $67.48 \%$, respectively. Previous preterm delivery and colonization by $G$. vaginalis were factors with very high OR, but only statistically significant for a $90 \% \mathrm{CI}$.

34 Conversely, higher rates of $G$. vaginalis colonization were found in women with basic 35 educational level $(\mathrm{OR}=2.77,95 \% \mathrm{CI}[1.33-5.78])$, during the second trimester of pregnancy $36(\mathrm{OR}=6.12,95 \% \mathrm{CI}[1.80-20.85])$ and with BV flora $(\mathrm{OR}=8.73,95 \% \mathrm{CI}[0.50-153.60])$. Discussion. Despite the lower number of women with BV, prevalence ratios and association with risk factors were similar to recent European studies. However, the percentage of healthy women colonized by $G$. vaginalis was significantly higher than many previous studies, confirming that $G$. vaginalis colonization does not always lead to BV development. 


\section{INTRODUCTION}

Worldwide, bacterial vaginosis (BV) is considered to be one of the most prevalent gynecological disorders of reproductive-age women and one of the most common causes of vaginal symptoms, prompting women to seek medical care (Sobel, 1997). This vaginal infection is microbiologically characterized by the replacement of a Lactobacillus-dominated vaginal microbiota by variable mixtures of strictly and facultative anaerobic bacteria including Gardnerella vaginalis, Atopobium vaginae and Mobiluncus spp. (Verhelst et al., 2004).

Currently, the presence of BV during pregnancy has attracted the attention of both clinicians and the scientific community, due to its relation with adverse pregnancy consequences such as preterm delivery (Leitich et al., 2003) and miscarriage (Leitich \& Kiss, 2007). The mechanisms involved in pregnancy complications induced by BV are not fully clarified, but many researchers suggest that preterm delivery results from bacteria ascension from vagina to the membranes and amniotic fluid (Goldenberg, Hauth \& Andrews, 2000; Pararas, Skevaki \& Kafetzis, 2006). In recent years, several studies demonstrated that the presence or high load of vaginal microbes associated to BV such as G. vaginalis, A. vaginae, Mobiluncus spp., Mycoplasma spp. and Leptotrichia/Sneathia species, were related with an increased risk of preterm birth (Foxman et al., 2014; Nelson et al., 2014; Bretelle et al., 2015; Kuon et al., 2017). However, the great diversity of vaginal microbiota in women with BV affects its potential to develop preterm birth and other negative outcomes in pregnancy (Hyman et al., 2014; Nelson et al., 2015) and it becomes BV treatment in pregnant women a challenging task (Haahr et al., 2016). Despite of its high impact, few epidemiological studies on BV have been conducted in Portugal (Guerreiro, Gigante \& Teles, 1998; Silva et al., 2014; Machado et al., 2015). Specifically, there is no information related to the prevalence of BV among Portuguese pregnant women. As such, we set this first epidemiological study aimed to determine the prevalences of BV and of G. vaginalis vaginal colonization in Portuguese pregnant women.

\section{MATERIALS \& METHODS}

\section{Population, data and biological samples collection}

This cross-sectional study involved pregnant women attending prenatal care consultations in two public Portuguese hospitals of the Northwest region (Hospital of Braga and Unidade Local de Saúde de Matosinhos), between May 2014 and May 2016. The inclusion criteria for the present 
76 study were: to be pregnant at any gestational age and to be older than 18 years. The exclusion

77 criteria were: women who were unable to read or understand Portuguese and who did not accept

78 to participate in study.

79 During prenatal care consultation, obstetricians invited all eligible women under their care to

80 participate in the study. All participants signed the informed consent form, as approved by the

81 respective local ethical committees. Afterwards, the participants were questioned by the

82 obstetricians about their age, educational level (basic, secondary or university), if they had

83 previous BV episodes, previous deliveries, history of preterm delivery, suffered of chronic

84 disease or smoking and about its use of intimate hygienic products and vitamin supplements, and

85 determined the current gestational period (first, second or third trimester). A short standardized

86 questionnaire was used to collect these data. Finally, the obstetricians collected vaginal samples

87 (only one sample point was taken for each participant), using sterile swab containing Amies

88 transport medium with coal (VWR, Radnor, PA, USA). After collection, the swabs were

89 immediately conserved at $4^{\circ} \mathrm{C}$ and transported to the Laboratory of Research in Biofilms Rosário

90 Oliveira of the University of Minho, where they were processed.

\section{Gram staining and BV diagnosis}

92 For BV diagnosis, a direct smear was performed by transferring the vaginal fluid present on the

93 swab to a glass slide. Then vaginal smears were heat-fixed and Gram stained (Spiegel, Amsel \&

94 Holmes, 1983). Afterwards, the smears were visualized using an Olympus BX51 microscope

95 (Olympus Portugal SA, Lisboa, Portugal) under oil immersion objective $(1000 \times$ magnification)

96 and, subsequently, graded in accordance with the Nugent scoring system (Nugent, Krohn \&

97 Hillier, 1991). In summary, on 10 microscopic fields, the following bacterial morphotypes were

98 identified and quantified: large gram-positive rods (Lactobacillus spp.), small gram-variable rods

99 (G. vaginalis), small gram-negative rods (Bacteroides spp.) and curved gram-variable rods

100 (Mobiluncus spp.). The sum of each morphotype score allowed to classify vaginal flora into

101 normal (score 0-3), intermediate (score 4-6) or BV (score 7-10).

102 Molecular detection of $\boldsymbol{G}$. vaginalis

103 Each vaginal swab was then immersed in $2 \mathrm{~mL}$ of $0.9 \%(\mathrm{wt} / \mathrm{v})$ of sodium chloride (Liofilchem,

104 Roseto degli Abruzzi, Italy) and the content was suspended using vigorous vortexing.

105 Afterwards, $1.5 \mathrm{~mL}$ of each diluted swab content was transferred into a tube that was centrifuged 106 at $8000 \mathrm{rpm}$, during 10 seconds, in order to allow for coal deposition at the bottom of the tube. 
107 Then, $0.6 \mathrm{~mL}$ of supernatant was collected to a new tube and this later was centrifuged at 13500

$108 \mathrm{rpm}$, during 5 minutes. At the end, the supernatant was discarded and the pellet was suspended in

$1090.1 \mathrm{~mL}$ of sterile ultra-pure water. This bacterial suspension was incubated in a heating block at

$11095^{\circ} \mathrm{C}$ for 20 minutes in order to disrupt bacterial cell wall and release the cell content, making

111 available the genomic DNA that is required for polymerase chain reaction (PCR). After

112 incubation, it was immediately cooled on ice for 5 minutes and the cell suspension was

113 centrifuged at $13500 \mathrm{rpm}$, during 5 minutes. The supernatant was used as template for a

114 multiplex PCR since we used the PCR to amplify different DNA sequences simultaneously

115 (namely gene encoding 16S rRNA of G. vaginalis and aap gene of Staphylococcus epidermidis).

116 Briefly, each PCR included $6 \mu \mathrm{L}$ of Dream Taq PCR Master Mix 2X (Thermo Fisher Scientific,

117 Waltham, MA, USA), $1 \mu \mathrm{L}$ of DNA from the vaginal sample, $2 \mu \mathrm{L}$ of distilled water

118 DNase/RNAse free (Thermo Fisher Scientific), $0.5 \mu \mathrm{L}$ of $5 \mu \mathrm{M}$ forward (FW1) G. vaginalis

119 primer, $0.5 \mu \mathrm{L}$ of $5 \mu \mathrm{M}$ reverse (RV1) G. vaginalis primer, $0.5 \mu \mathrm{L}$ of $5 \mu \mathrm{M}$ FW S. epidermidis

120 primer, $0.5 \mu \mathrm{L}$ of $5 \mu \mathrm{M}$ RV $S$. epidermidis primer and $1 \mu \mathrm{L}$ of complementary DNA of $S$.

121 epidermidis. Also, a negative control (containing $1 \mu \mathrm{L}$ of DNase/RNase free water instead of

122 genomic DNA) and positive control (containing $1 \mu \mathrm{L}$ of genomic DNA from pure culture of $G$.

123 vaginalis) were included in each set of reactions. The tubes were placed in a thermocycler (Bio-

$124 \mathrm{Rad}$, Hercules, CA, USA) that was programmed with the following protocol: $94^{\circ} \mathrm{C}$ for 2 minutes,

12540 steps of $94^{\circ} \mathrm{C}$ for 30 seconds, $60^{\circ} \mathrm{C}$ for 30 seconds, $72^{\circ} \mathrm{C}$ for 1 minute and finally $72^{\circ} \mathrm{C}$ for 5

126 minutes. The inclusion of the specific primers for the $S$. epidermidis aap gene acted as internal

127 positive control of PCR procedure, in order to ensure that amplifiable DNA was successfully

128 extracted and there are no PCR inhibitors on sample.

129 After the PCR reaction, amplified products were analyzed in $1 \%(\mathrm{wt} / \mathrm{v})$ of agarose $\left(\mathrm{SeaKem}^{\circledR}\right.$

130 LE, Rockland, ME, USA) gel with $0.05 \mu \mathrm{L} / \mathrm{mL}$ midori green nucleic acid dye (Nippon Genetics

131 Europe GmbH, Düren, Germany). The electrophoresis run for 50 minutes at 100 volts. Finally,

132 the results were visualized using the ChemiDoc (Bio-Rad) system, according to the

133 manufacturer's instructions. Negative results for the amplification of the gene encoding 16S

134 rRNA of $G$. vaginalis were confirmed using an independent set of primers (FW2/RV2). All

135 primers used are described in Table 1 and were previously assessed for specificity (França et al.,

136 2012; Henriques et al., 2012; Castro et al., 2017). 


\section{Statistical analysis}

139 Data were analyzed with GraphPad Prism version 6 (GraphPad Software Inc, La Jolla, CA,

140 USA). Firstly, we determined BV and G. vaginalis colonization prevalences and then we used

141 Chi-square or Fisher's exact test to verify whether BV positive status or G. vaginalis

142 colonization were associated with some sociodemographic, medical, reproductive, behavioral or

143 microbiological variables. A $p$-value $<0.05$ was used as threshold for statistically significance.

144 The strength of association between BV diagnosis or G. vaginalis colonization with the study

145 variables was assessed through calculation of odds ratios (OR) and their $95 \%$ confidence

146 intervals (CI).

147

\section{Ethical considerations}

149 The study was approved by the ethics committees of Unidade Local de Saúde de Matosinhos

150 (process 013/CE/JAS) and of Hospital of Braga (process SECVS 063/2014). All the study

151 participants agreed through informed consent to collaborate voluntarily, anonymously and freely.

152 To ensure confidentiality no personal data were recorded that could lead to identification of the 153 participants.

\section{RESULTS}

156 Between May 2014 and May 2016, a total of 273 women followed in prenatal care consultation

157 of two public Portuguese hospitals of the Northwest region agreed to participate in the current

158 study. Among them, 67 had uninterpretable Gram-staining slides and where excluded from this

159 study. Table 2 summarizes sociodemographic, medical, reproductive and behavioral

160 characteristics of the studied population $(n=206)$. The participants had ages comprised between

16119 and 41 years-old, resulting in mean age of $30.00 \pm 5.16$ years. Moreover, the majority of

162 participants was in the third trimester of pregnancy $(71.84 \%)$ and used vitamin supplementation $163(86.41 \%)$.

164 Among the 206 pregnant women, BV was diagnosed in only 8 participants, resulting in a BV 165 prevalence of $3.88 \%$ (Table 3). Probably due to the low number of BV cases, we did not found 166 any significant statistically association between BV and the risk factors considered in this study 167 ( $p$-value >0.05). Nevertheless, previous preterm delivery and colonization by $G$. vaginalis were 168 factors with very high OR, that could be considered statistically significant for a 90\% CI. 
169 Vaginal colonization by G. vaginalis was detected in 139 samples, representing a prevalence rate

170 of $67.48 \%$ (Table 4). Statistically significant differences between G. vaginalis positive and

171 negative groups were found in relation to maternal educational level, current pregnancy trimester

172 and vaginal microflora profile $(p$ value $<0.05)$. Of note that, basic educational level $(\mathrm{OR}=2.77$,

173 95\% CI [1.33-5.78]), second pregnancy trimester (OR $=6.12,95 \%$ CI [1.80-20.85]) and

174 presence of BV flora $(\mathrm{OR}=8.73,95 \% \mathrm{CI}[0.50-153.60])$ were associated with higher rates of $G$.

175 vaginalis colonization in these pregnant women.

176

177 DISCUSSION

178 This is the first epidemiological study conducted in Portugal with the aim to assess the

179 prevalence of BV among pregnant women, as well as to identify risk factors for BV and $G$.

180 vaginalis colonization during pregnancy. In contrast with the high frequency of G. vaginalis, BV

181 was diagnosed in only $3.88 \%$ of studied population. This BV prevalence rate is much lower than

182 that reported by other Portuguese studies (Guerreiro, Gigante \& Teles, 1998; Machado et al.,

183 2015). Indeed, Guerreiro et al. detected a BV prevalence of 7\% among 840 contraceptive users

184 living in Lisbon region (Guerreiro, Gigante \& Teles, 1998) while Machado et al. found a BV rate

185 of 17.33\%, among 150 young Portuguese women (Machado et al., 2015). Despite the lower

186 cases of pregnant women with BV reported in this study, our results were consistent with other

187 European studies. Cristiano et al. described a BV prevalence rate of $4.9 \%$ in 1441 Italian

188 pregnant women (Cristiano et al., 1996) while Gratacós and co-workers found BV in 4.5\%

189 among 492 Spanish women with low risk pregnancies (Gratacós et al., 1999). Akinbiyi and

190 colleagues conducted a randomized prospective study to determine the prevalence and age

191 distribution of Candida albicans and BV among English pregnant women, and found a BV

192 prevalence of $3.54 \%$ (38/1073) with the majority of BV cases belonging to the age group of 21-

19330 years (Akinbiyi, Watson \& Feyi-Waboso, 2008).

194 Contrasting with the very low prevalence of BV, in our study population, we found a $G$.

195 vaginalis colonization rate of $67.48 \%$. A significant higher colonization by G. vaginalis not

196 associated to BV has been reported elsewhere (Cox et al., 2016; Janulaitiene et al., 2017).

197 However, other epidemiological studies reported G. vaginalis colonization rates much lower than

198 ours (Pépin et al., 2011; Schwebke, Flynn \& Rivers, 2014; Silva et al., 2014). These differences

199 might be the result of significant different populations at study. In fact, recent genomic studies 
200 described that vaginal microbiome in pregnancy is unique and distinct of the non-pregnant

201 women (Aagaard et al., 2012; Jespers et al., 2015).

202 The observation that G. vaginalis colonization is not sufficient to cause BV, is not new

203 (Aroutcheva et al., 2001; Fredricks et al., 2007; Menard et al., 2008). However, recent genomic

204 studies have highlighted that G. vaginalis found in healthy women have distinct genetic profiles

205 than isolates from women with BV (Schellenberg et al., 2016; Janulaitiene et al., 2017).

206 Interestingly, it has been proposed that some of the known G. vaginalis genotypes are, in fact,

207 distinct species (Cerca et al., 2017). This is supported by full genome sequence analysis and

208 microbiology functional studies (Harwich et al., 2010; Yeoman et al., 2010; Castro et al., 2015).

209

210 CONCLUSIONS

211 For the first time, BV and G. vaginalis prevalence among Portuguese pregnant women were

212 determined. We found that BV prevalence was low but $G$. vaginalis colonization was very high.

213 Importantly, due to the small sample size, associations between BV and potential risk factors

214 should be made with caution and as such, further studies involving a large number of participants

215 and in different regions of the country should be performed in the future, to confirm our

216 observations.

217

218 ACKNOWLEDGMENTS

219 We would like to thank the medical doctors of the Obstetrics and Gynecology of Hospital of

220 Braga and Unidade Local de Saúde de Matosinhos, namely: Joana Barros, Bárbara Ribeiro,

221 Catarina Peixinho, Catarina Vieira, Joana Félix, Leonor Bivar, Luís Braga, for technical support

222 in collection of vaginal samples.

223

224

225

226

227

228

229

230

\section{REFERENCES}

Aagaard K., Riehle K., Ma J., Segata N., Mistretta TA., Coarfa C., Raza S., Rosenbaum S., Van den Veyver I., Milosavljevic A., Gevers D., Huttenhower C., Petrosino J., Versalovic J. 2012. A metagenomic approach to characterization of the vaginal microbiome signature in pregnancy. PLoS One 7:e36466. DOI: 10.1371/journal.pone.0036466.

Akinbiyi AA., Watson R., Feyi-Waboso P. 2008. Prevalence of Candida albicans and bacterial vaginosis in asymptomatic pregnant women in South Yorkshire, United Kingdom: Outcome 
231

232

233

234

235

236

237

238

239

240

241

242

243

244

245

246

247

248

249

250

251

252

253

254

255

256

257

258

259

260

261

of a prospective study. Archives of Gynecology and Obstetrics 278:463-466. DOI: 10.1007/s00404-008-0593-8.

Aroutcheva AA., Simoes JA., Behbakht K., Faro S. 2001. Gardnerella vaginalis isolated from patients with bacterial vaginosis and from patients with healthy vaginal ecosystems. Clinical Infectious Diseases 33:1022-1027. DOI: 10.1086/323030.

Bretelle F., Rozenberg P., Pascal A., Favre R., Bohec C., Loundou A., Senat MV., Aissi G., Lesavre N., Brunet J., Heckenroth H., Luton D., Raoult D., Fenollar F., Groupe de Recherche en Obstetrique Gynecologie. 2015. High Atopobium vaginae and Gardnerella vaginalis vaginal loads are associated with preterm birth. Clinical Infectious Diseases 60:860-867. DOI: 10.1093/cid/ciu966.

Castro J., Alves P., Sousa C., Cereija T., França Â., Jefferson KK., Cerca N. 2015. Using an invitro biofilm model to assess the virulence potential of bacterial vaginosis or non-bacterial vaginosis Gardnerella vaginalis isolates. Scientific Reports 5:11640. DOI: $10.1038 /$ srep 11640 .

Castro J., França A., Bradwell KR., Serrano MG., Jefferson KK., Cerca N. 2017. Comparative transcriptomic analysis of Gardnerella vaginalis biofilms vs. planktonic cultures using RNA-seq. npj Biofilms and Microbiomes 3:3. DOI: 10.1038/s41522-017-0012-7.

Cerca N., Vaneechoutte M., Guschin A., Swidsinski A. 2017. Polymicrobial infections and biofilms in women's health Gahro Expert Group Meeting Report 2017. Research in Microbiology pii: S0923-2508(17)30129-8. DOI: 10.1016/j.resmic.2017.07.002.

Cox C., Watt AP., McKenna JP., Coyle PV. 2016. Mycoplasma hominis and Gardnerella vaginalis display a significant synergistic relationship in bacterial vaginosis. European Journal of Clinical Microbiology and Infectious Diseases 35:481-487. DOI: 10.1007/s10096-015-2564-X.

Cristiano L., Rampello S., Noris C., Valota V. 1996. Bacterial vaginosis: prevalence in an Italian population of asymptomatic pregnant women and diagnostic aspects. European journal of epidemiology 12:383-390.

Foxman B., Wen A., Srinivasan U., Goldberg D., Marrs CF., Owen J., Wing DA., Misra D. 2014. Mycoplasma, bacterial vaginosis-associated bacteria BVAB3, race, and risk of preterm birth in a high-risk cohort. American Journal of Obstetrics and Gynecology 210:226.e1-7. DOI: 10.1016/j.ajog.2013.10.003. 
262 França A., Freitas AI., Henriques AF., Cerca N. 2012. Optimizing a qPCR gene expression

263

264

265

266

267

268

269

270

271

272

273

274

275

276

277

278

279

280

281

282

283

284

285

286

287

288

289

290

291

292 quantification assay for S. epidermidis biofilms: a comparison between commercial kits and a customized protocol. PLoS One 7:e37480. DOI: 10.1371/journal.pone.0037480.

Fredricks DN., Fiedler TL., Thomas KK., Oakley BB., Marrazzo JM. 2007. Targeted PCR for detection of vaginal bacteria associated with bacterial vaginosis. Journal of Clinical Microbiology 45:3270-3276. DOI: 10.1128/JCM.01272-07.

Goldenberg RL., Hauth JC., Andrews WW. 2000. Intrauterine infection and preterm delivery. The New England Journal of Medicine 342:1500-1507. DOI: 10.1056/NEJM200005183422007.

Gratacós E., Figueras F., Barranco M., Ros R., Andreu A., Alonso PL., Cararach V. 1999. Prevalence of bacterial vaginosis and correlation of clinical to Gram stain diagnostic criteria in low risk pregnant women. European Journal of Epidemiology 15:913-916.

Guerreiro D., Gigante MA., Teles LC. 1998. Sexually transmitted diseases and reproductive tract infections among contraceptive users. International Journal of Gynaecology and Obstetrics 63:S167-173.

Haahr T., Ersbøll AS., Karlsen MA., Svare J., Sneider K., Hee L., Weile LK., Ziobrowska-Bech A., Østergaard C., Jensen JS., Helmig RB., Uldbjerg N. 2016. Treatment of bacterial vaginosis in pregnancy in order to reduce the risk of spontaneous preterm delivery - a clinical recommendatio. Acta Obstetricia et Gynecologica Scandinavica 95:850-860. DOI: 10.1111/aogs.12933.

Harwich MD., Alves JM., Buck GA., Strauss JF., Patterson JL., Oki AT., Girerd PH., Jefferson KK. 2010. Drawing the line between commensal and pathogenic Gardnerella vaginalis through genome analysis and virulence studies. BMC Genomics 11:375. DOI: 10.1186/1471-2164-11-375.

Henriques A., Cereija T., Machado A., Cerca N. 2012. In silico vs in vitro analysis of primer specificity for the detection of Gardnerella vaginalis, Atopobium vaginae and Lactobacillus spp. BMC Research Notes 5:637. DOI: 10.1186/1756-0500-5-637.

Hyman RW., Fukushima M., Jiang H., Fung E., Rand L., Johnson B., Vo KC., Caughey AB., Hilton JF., Davis RW., Giudice LC. 2014. Diversity of the vaginal microbiome correlates with preterm birth. Reproductive Sciences 21:32-40. DOI: 10.1177/1933719113488838.

Janulaitiene M., Paliulyte V., Grinceviciene S., Zakareviciene J., Vladisauskiene A., Marcinkute 
293

294

295

296

297

298

299

300

301

302

303

304

305

306

307

308

309

310

311

312

313

314

315

316

317

318

319

320

321

322

323

A., Pleckaityte M. 2017. Prevalence and distribution of Gardnerella vaginalis subgroups in women with and without bacterial vaginosis. BMC Infectious Diseases 17:394. DOI: 10.1186/s12879-017-2501-y.

Jespers V., van de Wijgert J., Cools P., Verhelst R., Verstraelen H., Delany-Moretlwe S., Mwaura M., Ndayisaba GF., Mandaliya K., Menten J., Hardy L., Crucitti T., Vaginal Biomarkers Study Group. 2015. The significance of Lactobacillus crispatus and L. vaginalis for vaginal health and the negative effect of recent sex: a cross-sectional descriptive study across groups of African women. BMC Infectious Diseases 15:115. DOI: 10.1186/s12879-015-0825-z.

Kuon RJ., Togawa R., Vomstein K., Weber M., Goeggl T., Strowitzki T., Markert UR., Zimmermann S., Daniel V., Dalpke AH., Toth B. 2017. Higher prevalence of colonization with Gardnerella vaginalis and gram-negative anaerobes in patients with recurrent miscarriage and elevated peripheral natural killer cells. Journal of Reproductive Immunology 120:15-19. DOI: 10.1016/j.jri.2017.03.001.

Leitich H., Bodner-Adler B., Brunbauer M., Kaider A., Egarter C., Husslein P. 2003. Bacterial vaginosis as a risk factor for preterm delivery: a meta-analysis. American Journal of Obstetrics and Gynecology 189:139-147. DOI: 10.1067/mob.2003.339.

Leitich H., Kiss H. 2007. Asymptomatic bacterial vaginosis and intermediate flora as risk factors for adverse pregnancy outcome. Best Practice and Research: Clinical Obstetrics and Gynaecology 21:375-390. DOI: 10.1016/j.bpobgyn.2006.12.005.

Machado A., Castro J., Cereija T., Almeida C., Cerca N. 2015. Diagnosis of bacterial vaginosis by a new multiplex peptide nucleic acid fluorescence in situ hybridization method. PeerJ 3:e780. DOI: 10.7717/peerj.780.

Menard JP., Fenollar F., Henry M., Bretelle F., Raoult D. 2008. Molecular quantification of Gardnerella vaginalis and Atopobium vaginae loads to predict bacterial vaginosis. Clinical Infectious Diseases 47:33-43. DOI: 10.1086/588661.

Nelson DB., Hanlon A., Nachamkin I., Haggerty C., Mastrogiannis DS., Liu C., Fredricks DN. 2014. Early pregnancy changes in bacterial vaginosis-associated bacteria and preterm delivery. Paediatric and Perinatal Epidemiology 28:88-96. DOI: 10.1111/ppe.12106.

Nelson DB., Hanlon AL., Wu G., Liu C., Fredricks DN. 2015. First trimester levels of BVassociated bacteria and risk of miscarriage among women early in pregnancy. Maternal and 
324

325

326

327

328

329

330

331

332

333

334

335

336

337

338

339

340

341

342

343

344

345

346

347

348

349

350

351

352

353

354

Child Health Journal 19:2682-2687. DOI: 10.1007/s10995-015-1790-2.

Nugent RP., Krohn MA., Hillier SL. 1991. Reliability of diagnosing bacterial vaginosis is improved by a standardized method of gram stain interpretation. Journal of Clinical Microbiology 29:297-301.

Pararas MV., Skevaki CL., Kafetzis DA. 2006. Preterm birth due to maternal infection: causative pathogens and modes of prevention. European Journal of Clinical Microbiology and Infectious Diseases 25:562-569. DOI: 10.1007/s10096-006-0190-3.

Pépin J., Deslandes S., Giroux G., Sobéla F., Khonde N., Diakité S., Demeule S., Labbé AC., Carrier N., Frost E. 2011. The complex vaginal flora of West African women with bacterial vaginosis. PloS One 6:e25082. DOI: 10.1371/journal.pone.0025082.

Schellenberg JJ., Paramel Jayaprakash T., Withana Gamage N., Patterson MH., Vaneechoutte M., Hill JE. 2016. Gardnerella vaginalis subgroups defined by cpn60 sequencing and sialidase activity in isolates from Canada, Belgium and Kenya. PLoS One 11:e0146510. DOI: 10.1371/journal.pone.0146510.

Schwebke JR., Flynn MS., Rivers CA. 2014. Prevalence of Gardnerella vaginalis among women with Lactobacillus-predominant vaginal flora. Sexually Transmitted Infections 90:61-63. DOI: $10.1136 /$ sextrans-2013-051232.

Silva D., Henriques A., Cereija T., Martinez-de-Oliveira J., Miranda M., Cerca N. 2014. Prevalence of Gardnerella vaginalis and Atopobium vaginae in Portuguese women and association with risk factors for bacterial vaginosis. International Journal of Gynaecology and Obstetrics 124:178-179. DOI: 10.1016/j.ijgo.2013.08.008.

Sobel JD. 1997. Current Concepts: Vaginitis. The New England journal of medicine 337:18961903. DOI: 10.1056/NEJM199712253372607.

Spiegel CA., Amsel R., Holmes KK. 1983. Diagnosis of bacterial vaginosis by direct gram stain of vaginal fluid. Journal of Clinical Microbiology 18:170-177.

Verhelst R., Verstraelen H., Claeys G., Verschraegen G., Delanghe J., Van Simaey L., De Ganck C., Temmerman M., Vaneechoutte M. 2004. Cloning of 16S rRNA genes amplified from normal and disturbed vaginal microflora suggests a strong association between Atopobium vaginae, Gardnerella vaginalis and bacterial vaginosis. BMC Microbiology 4:16. DOI: 10.1186/1471-2180-4-16.

Yeoman CJ., Yildirim S., Thomas SM., Durkin AS., Torralba M., Sutton G., Buhay CJ., Ding 
355 Y., Dugan-Rocha SP., Muzny DM., Qin X., Gibbs RA., Leigh SR., Stumpf R., White BA., 356 Highlander SK., Nelson KE., Wilson BA. 2010. Comparative genomics of Gardnerella 357 vaginalis strains reveals substantial differences in metabolic and virulence potential. PloS 358 One 5:e12411. DOI: 10.1371/journal.pone.0012411. 


\section{Table $\mathbf{1}$ (on next page)}

Primers used in this study.

Primers used in this study. 


\begin{tabular}{|c|c|c|c|c|c|}
\hline Target & Set & Sequence (5' to $\left.3^{\prime}\right)$ & $\mathrm{TM}\left({ }^{\circ} \mathrm{C}\right)$ & $\begin{array}{l}\text { Amplification } \\
\text { region (Genebank) }\end{array}$ & Reference \\
\hline \multirow{4}{*}{$\begin{array}{l}\text { G. vaginalis } \\
\text { 16SRNA }\end{array}$} & FW1 & CTCTTGGAAACGGGTGGTAA & 60 & \multirow{2}{*}{$\begin{array}{l}\text { KP996686.1 } \\
\text { (from } 99 \text { to } 399 \text { ) }\end{array}$} & \multirow{2}{*}{$\begin{array}{l}\text { (Henriques } \\
\text { et al., 2012) }\end{array}$} \\
\hline & RV1 & TTGCTCCCAATCAAAAGCGGT & 62 & & \\
\hline & FW2 & AGCCTAGGTGGGCCATTACC & 59 & \multirow{2}{*}{$\begin{array}{l}\text { KP996686.1 } \\
\text { (from } 206 \text { to } 373 \text { ) }\end{array}$} & \multirow{2}{*}{$\begin{array}{l}\text { (Castro et } \\
\text { al., 2017) }\end{array}$} \\
\hline & RV2 & TGAGTAATGCGTGACCAACC & 55 & & \\
\hline \multirow[t]{2}{*}{ S. epidermidis aap } & FW & GCACCAGCTGTTGTTGTACC & 59 & \multirow{2}{*}{$\begin{array}{l}\text { CP020463.1 } \\
\text { (from } 110863 \text { to } \\
111053 \text { ) }\end{array}$} & \multirow{2}{*}{$\begin{array}{l}\text { (França et } \\
\text { al., 2012) }\end{array}$} \\
\hline & $\mathrm{RV}$ & GCATGCCTGCTGATAGTTCA & 60 & & \\
\hline
\end{tabular}

\section{Notes.}

2 TM, melting temperature; FW, forward; RV, reverse. 
Table 2 (on next page)

Characteristics of the studied population

Characteristics of the studied population $(n=206)$. 


\begin{tabular}{|c|l|}
\hline Variables & $\%$ \\
\hline Sociodemographic & \\
\hline Age (mean \pm SD, years) & $30.00 \pm 5.16$ \\
\hline$<30$ years & 41.75 \\
\hline$\geq 30$ years & 58.25 \\
\hline Educational level & \\
\hline$\leq$ Basic & 29.13 \\
\hline Secondary & 35.44 \\
\hline$\geq$ University & 35.44 \\
\hline Medical & \\
\hline Previous BV & 7.77 \\
\hline History of chronic disease & 14.56 \\
\hline Reproductive & \\
\hline Previous delivery & 41.75 \\
\hline Previous preterm delivery & 6.80 \\
\hline Pregnancy trimester & \\
\hline First & 11.65 \\
\hline Second & 16.50 \\
\hline Third & 71.84 \\
\hline Behavioral & \\
\hline Tobacco consumption & 12.62 \\
\hline Use of intimate hygiene products & 28.64 \\
\hline Vitamin supplementation & \\
\hline
\end{tabular}

\section{Notes.}

$2 \mathrm{SD}$, standard deviation; BV, bacterial vaginosis.

3 Values are given as mean $\pm \mathrm{SD}$ or percentage $(\%)$. 


\section{Table 3(on next page)}

Characterization of women with or without BV

Sociodemographic, medical, reproductive, behavioral and microbiological variables among women with or without BV. 


\begin{tabular}{|c|c|c|c|c|c|}
\hline Variables & $\begin{array}{l}\text { BV positive } \\
(\mathrm{n}=8)\end{array}$ & $\begin{array}{l}\text { BV negative } \\
(\mathrm{n}=198)\end{array}$ & $p$ value & OR & $95 \% \mathrm{CI}$ \\
\hline \multicolumn{6}{|l|}{ Sociodemographic } \\
\hline Age (mean $\pm \mathrm{SD}$, years) & $32.00 \pm 3.16$ & $29.91 \pm 5.21$ & 0.14 & & \\
\hline$<30$ years & 1 & 85 & & 0.19 & $0.02-1.57$ \\
\hline$\geq 30$ years & 7 & 113 & & 5.27 & $0.64-43.63$ \\
\hline Educational level & & & 0.97 & & \\
\hline$\leq$ Basic & 2 & 58 & & 0.81 & $0.16-4.11$ \\
\hline Secondary & 3 & 70 & & 1.10 & $0.26-4.73$ \\
\hline$\geq$ University & 3 & 70 & & 1.10 & $0.26-4.73$ \\
\hline \multicolumn{6}{|l|}{ Medical } \\
\hline Previous BV & 2 & 14 & 0.12 & 4.38 & $0.81-23.75$ \\
\hline History of chronic disease & 3 & 27 & 0.09 & 3.80 & $0.86-16.83$ \\
\hline \multicolumn{6}{|l|}{ Reproductive } \\
\hline Previous delivery & 4 & 82 & 0.72 & 1.42 & $0.34-5.82$ \\
\hline Previous preterm delivery & 2 & 12 & 0.09 & 5.17 & $0.94-28.39$ \\
\hline Pregnancy trimester & & & 0.27 & & \\
\hline First & 2 & 22 & & 2.67 & $0.51-14.04$ \\
\hline Second & 0 & 34 & & 0.28 & $0.02-4.98$ \\
\hline Third & 6 & 142 & & 1.18 & $0.23-6.04$ \\
\hline \multicolumn{6}{|l|}{ Behavioral } \\
\hline Tobacco consumption & 0 & 26 & 0.60 & 0.38 & $0.02-6.84$ \\
\hline $\begin{array}{l}\text { Use of intimate hygiene } \\
\text { products }\end{array}$ & 4 & 55 & 0.23 & 2.60 & $0.63-10.76$ \\
\hline Vitamin supplementation & 7 & 171 & 1.00 & 1.11 & $0.13-9.35$ \\
\hline \multicolumn{6}{|l|}{ Microbiological } \\
\hline G. vaginalis presence & 8 & 131 & 0.06 & 8.73 & $0.50-153.60$ \\
\hline
\end{tabular}

\section{Notes.}

2 BV, bacterial vaginosis; OR, odds ratio; CI, confidence interval; SD, standard deviation.

3 Values are given as mean $\pm \mathrm{SD}$ or number. 


\section{Table 4 (on next page)}

Characterization of women with or without vaginal colonization by G. vaginalis

Sociodemographic, medical, reproductive, behavioral and microbiological variables among women with or without $G$. vaginalis colonization. 


\begin{tabular}{|c|c|c|c|c|c|}
\hline Variables & $\begin{array}{l}\text { GV positive } \\
(\mathrm{n}=139)\end{array}$ & $\begin{array}{l}\text { GV negative } \\
(\mathrm{n}=67)\end{array}$ & $p$ value & OR & $95 \% \mathrm{CI}$ \\
\hline \multicolumn{6}{|l|}{ Sociodemographic } \\
\hline Age (mean \pm SD, years) & $29.94 \pm 5.35$ & $30.12 \pm 4.78$ & 0.88 & & \\
\hline$<30$ years & 59 & 27 & & 1.09 & $0.60-1.98$ \\
\hline$\geq 30$ years & 80 & 40 & & 0.92 & $0.51-1.66$ \\
\hline Educational level & & & 0.02 & & \\
\hline$\leq$ Basic & 49 & 11 & & 2.77 & $1.33-5.78$ \\
\hline Secondary & 47 & 26 & & 0.81 & $0.44-1.47$ \\
\hline$\geq$ University & 43 & 30 & & 0.55 & $0.30-1.01$ \\
\hline \multicolumn{6}{|l|}{ Medical } \\
\hline Previous BV & 13 & 3 & 0.28 & 2.20 & $0.61-8.01$ \\
\hline History of chronic disease & 24 & 6 & 0.14 & 2.12 & $0.82-5.47$ \\
\hline \multicolumn{6}{|l|}{ Reproductive } \\
\hline Previous delivery & 62 & 24 & 0.29 & 1.44 & $0.79-2.63$ \\
\hline Previous preterm delivery & 9 & 5 & 0.77 & 0.86 & $0.28-2.67$ \\
\hline Pregnancy trimester & & & $<0.01$ & & \\
\hline First & 17 & 7 & & 1.19 & $0.47-3.04$ \\
\hline Second & 31 & 3 & & 6.12 & $1.80-20.85$ \\
\hline Third & 91 & 57 & & 0.33 & $0.16-0.71$ \\
\hline \multicolumn{6}{|l|}{ Behavioral } \\
\hline Tobacco consumption & 22 & 4 & 0.07 & 2.96 & $0.98-8.98$ \\
\hline $\begin{array}{l}\text { Use of intimate hygiene } \\
\text { products }\end{array}$ & 45 & 14 & 0.10 & 1.81 & $0.91-3.61$ \\
\hline Vitamin supplementation & 124 & 54 & 0.13 & 1.99 & $0.89-4.47$ \\
\hline Microbiological & & & 0.02 & & \\
\hline Normal flora & 94 & 56 & & 0.41 & $0.20-0.86$ \\
\hline Intermediate flora & 37 & 11 & & 1.85 & $0.87-3.90$ \\
\hline BV flora & 8 & 0 & & 8.73 & $0.50-153.60$ \\
\hline
\end{tabular}

1 Notes. 
2 GV, Gardnerella vaginalis; OR, odds ratio; CI, confidence interval; SD, standard deviation; BV, 3 bacterial vaginosis.

4 Values are given as mean $\pm \mathrm{SD}$ or number. 